\title{
CHANGE IN SALIVA PH FOLLOWING INTAKE OF SOME HOMEOPATHIC MEDICATIONS
}

\author{
Antoniya Pomakova, Nataliya Gateva, Nina Milcheva \\ Department of Pediatric Dental Medicine, Faculty of Dental Medicine, \\ Medical University of Varna
}

\begin{abstract}
INTRODUCTION: The role of simple carbohydrates as a major etiological factor for the carious process is well known. Studies have shown that frequent use of conventional sugar-containing medications increases the risk for oral health. Today, a significant proportion of the population chooses alternative medicine and particularly homeopathy for treatment and prophylaxis, considering it effective and safe. However, its influence on oral conditions and its involvement as a risk factor for oral health still remains an under-discussed topic.

MATERIALS AND METHODS: The study included 18 volunteer students in dental medicine. An in vitro saliva test with colored strips was used for four consecutive weeks and after intake of three commonly used homeopathic medications. The following entries were registered: baseline value, $15^{\text {th }}, 30^{\text {th }}$ and $60^{\text {th }}$ minute following the intake of the respective homeopathic doses. During the first week, the study was carried out without intake of any homeopathic medicine. The data was subjected to statistical analysis.

RESULTS: There was a fall in saliva $\mathrm{pH}$ following intake of homeopathic medications in all studied patients. The $\mathrm{pH}$ reduction was most significant at the $15^{\text {th }}$ minute, and the average drop for the three homeopathic medications was $-0.68,0.94,1.07$, respectively. $O$ n the $30^{\text {th }}$ and $60^{\text {th }}$ minute, the mean $\mathrm{pH}$ drop remained the highest for the third drug.

CONCLUSION: There was a decrease in saliva $\mathrm{pH}$ in all individuals after administration of each medication. In a significant part of the cases the drop was below the critical value of 5.5. The values remained lower than the baseline even an hour following the intake.
\end{abstract}

Keywords: homeopathy, saliva, salivary $\mathrm{pH}$, homeopathic medications, dental caries

Address for correspondence:

Antoniya Pomakova

Faculty of Dental Medicine

Medical University of Varna

84 Tsar Osvoboditel Blvd

Varna

e-mail:antoniya_pomakova@abv.bg

Received: May 2, 2017

Accepted: June 27, 2017

\section{INTRODUCTION}

Homeopathy is a well-defined scientific system, created in 1796 by Samuel Hahnemann, and based on the 'principle of similarity' (similia similibus curantur), i.e. like cures like (1-5). It is among the most popular alternative and complementary medicine approaches in modern times (6). Homeopathy is well accepted by patients as medications are easily avail- 
able (over the counter) and are prescribed for acute and chronic conditions (4).

Homeopathic medicines are prepared by repeatedly diluting a chosen substance in alcohol or distilled water, followed by forceful striking (i.e. succession) of the solution on an elastic object at every step of the dilution $(1,3,7)$. It is believed that each dilution, followed by succession, increases the drug potency (1). Usually insoluble substances are fine grinded and diluted with lactose (i.e. trituration), the final preparations being in liquid form or impregnated on sugar tablets $(3,7)$. They may be in the form of pellets, tablets, powder or liquid. The liquid, or the mother tincture, consists of an alcoholic extract of the specific drug (6). The liquid is generally placed under the tongue using a dropper, but since it contains alcohol it should not be given to children (6). The globules, tablets and pellets, which are made with a lactose base, dissolve in the mouth without chewing. For infants they can be dissolved in water and administered with a dropper (6). They are usually provided without prescription, made from natural extracts, are not toxic and have no potential side effects (4).

The role of sugar in dental caries etiology is clearly proven. After intake of fermentable carbohydrates, oral microorganisms, especially $S$. mutans, metabolise them and produce acids. They in turn reduce the local $\mathrm{pH}$ of the tooth biofilm to a level where the demineralisation processes prevail and a carious process begins (8-14). There are opinions that sugar content in homeopathic medications can also affect oral health (4). Consumer requirements for $100 \%$ natural products have increased significantly. For this reason, healthcare professionals are meeting more and more patients using complementary and alternative medicine, including homeopathy (15). These facts determine the need for more in-depth studies on the effects of homeopathic medications on the oral environment and hence on oral health (4).

This study aims to evaluate the dynamics of $\mathrm{pH}$ values change in unstimulated saliva following the intake of three commonly used homeopathic medications. The scientific hypothesis is that the intake of these homeopathic drugs shall result in a rapid drop in saliva $\mathrm{pH}$ under the critical value of 5.5 and such drop will remain within an hour time.

\section{MATERIALS AND METHODS}

The study includes 18 volunteer students in dental medicine. Criteria for inclusion are candidates to be completely healthy and not to be subject to any kind of medication that would change the saliva characteristics. A week prior to the start of the study, every volunteer underwent professional oral hygiene procedures. Participants were given the same instructions for conducting oral hygiene and the same toothpaste was recommended. All volunteers had sanitised dentition and no gingival inflammation. Prior to the study, its essence was explained to participants so that they could provide an informed consent.

The study was conducted once a week on a selected day for four consecutive weeks. To avoid the effects of circadian rhythms, the tests were done in the morning, at least one hour after breakfast and standard oral hygiene, between 8 and $11 \mathrm{am}$. Until the beginning and during the study, volunteers did not take any food or drink.

The unstimulated saliva was tested. The volunteers provided 1-2 spit samples in a sample cup. An in-vitro GC Saliva Check test was applied with a test strip that changed its colour depending on the $\mathrm{pH}$ level. The saliva $\mathrm{pH}$ of each participant was measured then at baseline and at the $15^{\text {th }}, 30^{\text {th }}$ and $60^{\text {th }}$ minute after the homeopathic medication intake.

Three of the most frequently used homeopathic remedies were selected (according to our survey). These are homeopathic pellets to stimulate the immune system (№1); a homeopathic cough syrup (№2); and homeopathic granules with pain relief, soothing effect and often used in case of teeth eruption discomfort (№3). The first one contains animal derived sources - heart and liver and added sugars - sucrose and lactose. It is taken 2-3 times daily, 15 minutes before or one hour after a meal. The second one contains components of plant and animal origin with added ethanol and sucrose. The intake is 3-5 times a day between meals. The third medication is chamomile-based and 3-5 granules are usually taken unlimited times during the day.

During the first week of the study, saliva $\mathrm{pH}$ was measured at the appropriate time intervals without medication intake. Thus, the saliva $\mathrm{pH}$ values serving as baseline control (control group - group 1) 
were determined. During the second week, on a given day, after measuring the baseline $\mathrm{pH}$, one dose of pills of medication №1 was administered under the tongue until complete dissolution and then the $\mathrm{pH}$ was measured at the $15^{\text {th }}, 30^{\text {th }}$ and $60^{\text {th }}$ minute. The measured saliva $\mathrm{pH}$ values following the administration of medication № 1 constituted data defined as group 2. During the third week, on the given day, the same schedule was repeated as in the second week but with a dose of $15 \mathrm{ml}$ of the homeopathic syrup (drug № 2). The registered values formed the data of group 3 . On the designated day of the fourth week, 5 granules of the homeopathic preparation № 3 were placed and kept under the tongue until complete dissolution. The measured saliva $\mathrm{pH}$ values formed the data of group 4. All results were documented in an individual card for each volunteer. Based on the knowledge of the saliva buffer capacity and the quick drop in $\mathrm{pH}$ below the critical values after intake of simple carbohydrates and its slow rise to baseline, requiring 15 to 40 minutes (demonstrated by the Stefan curve), we decided to register the change in saliva $\mathrm{pH}$ at the $15^{\text {th }}, 30^{\text {th }}$ and $60^{\text {th }}$ minute. The objective was to represent in a better way the dynamics of $\mathrm{pH}$ change and its possible role as a risk factor for the development of dental caries based on the prolonged acidity that develops after taking a homeopathic medication.
The statistical processing of the results included the determination of the number of existing drops in different groups, as well as their percentage to the total number in the groups. An ANOVA analysis was performed to verify the differences between the calculated mean values - relative proportion and mean value of the observed drop in saliva $\mathrm{pH}$. For level of significance was adopted the $p$ value - sig. $<0.05$. The data was analysed using SPSS-19 software.

\section{RESULTS}

Table 1 shows the relative proportion of individuals with a drop in saliva $\mathrm{pH}$ with and without a homeopathic medication intake and the corresponding minute of the measurement.

At the $15^{\text {th }}$ minute following the intake of each of the three tested homeopathic preparations, a decrease in saliva $\mathrm{pH}$ was observed in $100 \%$ of the volunteers (group 2, 3 and 4, Table 1). A drop was reported in two subjects from the control group (Table 1). The $\mathrm{pH}$ level following the intake of a homeopathic drug remained lower than the baseline value until the end of the study ( $60^{\text {th }}$ minute) in over $80 \%$ of the cases, while for group 4 the saliva $\mathrm{pH}$ remained lower in all subjects (Table 1). At the $30^{\text {th }}$ minute recovery of baseline $\mathrm{pH}$ was observed in two subjects from

Table. 1. Average proportion of individuals with a drop of salivary $\mathrm{pH}$ within an hour, with and without intake of homeopathic medication

\begin{tabular}{lc|c|c|} 
Groups & $\mathbf{1 5}^{\text {th }}$ min. & $\mathbf{3 0}^{\text {th }}$ min. & $\mathbf{6 0}^{\text {th }} \mathbf{m i n}$. \\
Group 1 (control) & number \% indiv. & number \% indiv. & number \% indiv. \\
Group 2 (medication 1, pellets) & $2-11.1 \%$ & $1-5.6 \%$ & $1-5.6 \%$ \\
Group 3 (medication 2, syrup) & $18-100 \%$ & $16-88.9 \%$ & $16-88.9 \%$ \\
Group 4 (medication 3, granules) & $18-100 \%$ & $18-100 \%$ & $15-83.3 \%$ \\
Total & $18-100 \%$ & $18-100 \%$ & $18-100 \%$ \\
\hline
\end{tabular}

Table. 2. Average level of salivary $\mathrm{pH}$ drop in all groups in the relevant time intervals

\begin{tabular}{|c|c|c|c|c|c|c|c|}
\hline \multirow{2}{*}{ GROUP } & \multicolumn{7}{|c|}{ Average level pf salivary pH drop } \\
\hline & Basic level & $15^{\text {th }} \min$. & Difference & $30^{\text {th }} \mathrm{min}$. & Difference & $60^{\text {th }} \mathrm{min}$. & Difference \\
\hline Group 1 & 6.59 & 6.61 & +0.02 & 6.63 & +0.04 & 6.64 & +0.06 \\
\hline Group 2 & 6.64 & 5.96 & -0.68 & 6.15 & -0.49 & 6.23 & -0.41 \\
\hline Group 3 & 6.67 & 5.72 & -0.94 & 5.90 & -0.77 & 6.20 & -0.47 \\
\hline Group 4 & 6.61 & 5.54 & -1.07 & 5.79 & -0.82 & 6.02 & -0.59 \\
\hline Total & 6.63 & 5.96 & -0.67 & 6.12 & -0.51 & 6.27 & -0.35 \\
\hline
\end{tabular}


Antoniya Pomakova, Nataliya Gateva, Nina Milcheva

Group 2 and at the $60^{\text {th }}$ minute such recovery of baseline $\mathrm{pH}$ was recorded in three subjects from group 3.

Table 2 shows the mean value of saliva $\mathrm{pH}$ drop in each group at the measured minute intervals.

The highest mean drop in saliva $\mathrm{pH}$, by 1.07 , was recorded at the $15^{\text {th }}$ minute in group 4 (Table 2). This trend was retained for the same group even at the $60^{\text {th }}$ minute, with a mean value of $\mathrm{pH}$ drop by 0.59 (Table 2).

Table 3 also shows the drop in saliva $\mathrm{pH}$ for the tested minute intervals, indicating the number (and relative proportion) of patients in the relevant group with saliva $\mathrm{pH}$ below 5.5 and in the range 5.5-6.0. liva $\mathrm{pH}$ drop for the individual groups. The results obtained are shown in Table 4.

A significant drop in mean saliva $\mathrm{pH}$ values was recorded in groups 3 and 4 compared to the other two groups. The differences between group 3 and 4 are statistically insignificant. Group 2 ranked second in terms of drop in the mean $\mathrm{pH}$ values. In group 1 , only one drop was recorded and therefore it was excluded from the analysis.

The comparison in pairs between all groups established the following dependencies: statistically significant difference in the mean $\mathrm{pH}$ drop at the $15^{\text {th }}$ minute ( $\mathrm{p}<0.00$, Table 4$)$ was found in all oth-

Table 3. Number of individuals in the relevant groups with a drop of salivary pH under 5.5 and in the range of 5.5-6 at different time intervals

\begin{tabular}{|c|c|c|c|c|c|c|c|c|c|c|c|c|}
\hline \multirow{3}{*}{ Group } & \multicolumn{4}{|c|}{ Drop $15^{\text {th }}$} & \multicolumn{4}{|c|}{ Drop $30^{\text {th }}$} & \multicolumn{4}{|c|}{ Drop $60^{\text {th }}$} \\
\hline & \multicolumn{2}{|c|}{ under 5.5} & \multicolumn{2}{|c|}{$5.5-6.0$} & \multicolumn{2}{|c|}{ under 5.5} & \multicolumn{2}{|c|}{$5.5-6.0$} & \multicolumn{2}{|c|}{ under 5.5} & \multicolumn{2}{|c|}{$5.5-6.0$} \\
\hline & $\begin{array}{l}\text { num- } \\
\text { ber }\end{array}$ & $\%$ & $\begin{array}{l}\text { num- } \\
\text { ber }\end{array}$ & $\%$ & $\begin{array}{l}\text { num- } \\
\text { ber }\end{array}$ & $\%$ & $\begin{array}{l}\text { num- } \\
\text { ber }\end{array}$ & $\%$ & $\begin{array}{l}\text { num- } \\
\text { ber }\end{array}$ & $\%$ & $\begin{array}{l}\text { num- } \\
\text { ber }\end{array}$ & $\%$ \\
\hline 1 & 0 & $0.0 \%$ & 0 & $0.0 \%$ & 0 & $0.0 \%$ & 0 & $0.0 \%$ & 0 & $0.0 \%$ & 0 & $0.0 \%$ \\
\hline 2 & 2 & $11.1 \%$ & 4 & $22.2 \%$ & 1 & $5.6 \%$ & 4 & $22.2 \%$ & 0 & $0.0 \%$ & 5 & $27.8 \%$ \\
\hline 3 & 8 & $44.4 \%$ & 2 & $11.1 \%$ & 2 & $11.1 \%$ & 7 & $38.9 \%$ & 0 & $0.0 \%$ & 5 & $27.8 \%$ \\
\hline 4 & 10 & $55.6 \%$ & 5 & $27.8 \%$ & 4 & $22.2 \%$ & 9 & $50.0 \%$ & 2 & $11.1 \%$ & 4 & $22.2 \%$ \\
\hline
\end{tabular}

In group 4 at the $15^{\text {th }}$ minute a mean drop in salivary $\mathrm{pH}$ below the critical value (5.5) was recorded in 10 subjects. At the $30^{\text {th }}$ minute this number was 4 , and at the $60^{\text {th }}$ minute two persons indicated a value below the critical $\mathrm{pH}$. The highest incidence was of subjects with a $\mathrm{pH}$ drop in the range of 5.5-6 for the same group and for all control time intervals (Table 3). In group 3, eight volunteers showed minute drop in saliva $\mathrm{pH}$ below 5.5 at the $15^{\text {th }}$ and two of the subjects - at the $30^{\text {th }}$ minute. In seven of the subjects in the same group a drop to the range of 5.5-6 was recorded at the $30^{\text {th }}$ minute. At the $60^{\text {th }}$ minute, this number dropped to five, with no registered values below 5.5. In group 2 , at the $15^{\text {th }}$ minute, two volunteers showed a drop below 5.5, though at the $60^{\text {th }}$ minute none was in this range. In the same group at the $15^{\text {th }}$ minute four of the respondents had a saliva $\mathrm{pH}$ drop to $5.5-6$, and on the $60^{\text {th }}$ minute for five individuals it remained in the same range.

An ANOVA analysis was also used to verify the differences between the calculated mean values of sa- er groups except for group 1. Statistically significant drops in $\mathrm{pH}$ were found at the $15^{\text {th }}$ minute between group 2 and group $4(\mathrm{p}<0.003)$. A difference in the mean $\mathrm{pH}$ drop between group 2 and group 3 $(\mathrm{p}<0.036$, Table 4$)$ and between group 2 and group 4 $(\mathrm{p}<0.00$, Table 4$)$ at the $30^{\text {th }}$ minute was determined as significant. At the $60^{\text {th }}$ minute the recorded mean values of $\mathrm{pH}$ drop in groups 2, 3 and 4 were statistically insignificant.

\section{DISCUSSION}

According to statistical analyses, on average $60 \%$ of the population in developed countries takes some form of medicine, of which about half are taken without prescription (16). In regard to children, 17\% of them are given non-prescription cough medicines (17). Analgesics, cough medicines and multivitamins are the most commonly used non-prescription liquid medications $(16,18)$. It has been shown that these present a risk factor for the development of a dental caries process (19-23). The characteristics determining the cariogenic potential of the medication are the 
Change in Saliva pH Following Intake of Some Homeopathic Medications

Table 4. Difference in the average levels of salivary $\mathrm{pH}$ drop between the groups in the relevant time intervals

\begin{tabular}{|c|c|c|c|c|c|}
\hline \multirow{2}{*}{ Time interval } & \multirow{2}{*}{ Group } & \multirow{2}{*}{$\begin{array}{l}\text { Compared with } \\
\text { group }\end{array}$} & \multicolumn{2}{|c|}{$95 \%$ confidence interval } & \multirow{2}{*}{$\mathrm{P}^{\star}$} \\
\hline & & & Lower limit & Upper limit & \\
\hline \multirow{6}{*}{$15^{\text {th }}$ minute } & \multirow{3}{*}{ Group 1} & Group 2 & 0.286159 & 0.680507 & 0.000 \\
\hline & & Group 3 & 0.456699 & 1.032190 & 0.000 \\
\hline & & Group 4 & 0.646301 & 1.087032 & 0.000 \\
\hline & \multirow{2}{*}{ Group 2} & Group 3 & -0.069112 & 0.591334 & 0.185 \\
\hline & & Group 4 & 0.105422 & 0.661244 & 0.002 \\
\hline & Group 3 & Group 4 & -0.219574 & 0.464019 & 0.904 \\
\hline \multirow{3}{*}{$30^{\text {th }}$ minute } & \multirow{2}{*}{ Group 2} & Group 3 & 0.013373 & 0.407460 & 0.036 \\
\hline & & Group 4 & 0.068929 & 0.463016 & 0.009 \\
\hline & Group 3 & Group 4 & -0.135605 & 0.246718 & 0.561 \\
\hline \multirow{3}{*}{$60^{\text {th }}$ minute } & \multirow{2}{*}{ Group 2} & Group 3 & -0.065230 & 0.286897 & 0.211 \\
\hline & & Group 4 & -0.041932 & 0.294710 & 0.137 \\
\hline & Group 3 & Group 4 & -0.155710 & 0.186821 & 0.856 \\
\hline
\end{tabular}

${ }^{\star}$ Empirical level of scientific significance (ANOVA)

sucrose content, the acidic nature of the drug and the individual salivation and salivary buffer capacity $(20,24,25)$. Pierro et al. (21) mention the following characteristics as defining for the cariogenic potential of the drug: sugar content, frequency, dose, and route of administration.

Homeopathy is one of the most commonly used alternative medicine systems (5). Clinical experience in this field suggests that homeopathy is effective, relatively inexpensive, and patients are satisfied and rarely experience side effects (26). This type of medication has a convenient form, sweet and pleasant taste. The intake of a homeopathic medication should be at least 15 minutes before or after meals (6). During homeopathy treatment toothpastes without sweeteners, synthetic deodorants, bleaching agents, artificial colors or fragrances, detergents, and mint should also be used (6). The toothpastes should not contain fluorides (6). Homeopathic medications are prescribed with frequent intake - usually 3-4 times a day, and sometimes every two hours, on a regular basis and at night before bedtime (4). The results we obtained indicate that in such a situation this will cause drop in the saliva $\mathrm{pH}$ and maintenance of a long-lasting acidity over a long period of time (Tables 2 and 3).

According to Subramaniam and Kumar (4), the sugar content of homeopathic medical products can also affect oral health. Sugar in homeopathy, according to the authors, cannot be defined exactly as "hid- den sugar". It is rather "ignored", "missed". Five pellets, taken 4 times a day, contain a total of 1 gram of sugar (28).

It has been found that adult patients prefer taking a homeopathic remedy instead of an antibiotic because they believe that the latter will suppress the immune system and prevent their healing. Many of them are mothers who apply the same beliefs to the treatment of their children (27). Children are more prone to recurring colds, and many parents prefer homeopathic remedies to allopathic ones because of the absence of side effects (4). In many families, homeopathy is a choice of treatment in the case of recurrent illnesses and/or chronic ones (colds, runny nose, diarrhea, asthma, nausea and vomiting, headache, mucosal inflammation, colic in babies, etc.) (4). Although parents are aware of the sweetness and taste of homeopathic medications, they probably do not pay attention to the possible effects that these granules may have on their children's oral health (4).

Subramaniam and Kumar have conducted a similar to our study to find the change in saliva $\mathrm{pH}$ after taking homeopathic drugs (4). Some of the drugs they studied are the same as ours. The drugs they use are chamomilla $2 \mathrm{x}$ and arsenic $2 \mathrm{x}$. The results show a significant drop in saliva $\mathrm{pH}$ (below the critical 5.5), which coincides with the values we have obtained (Table 3). Prolonged maintenance of low salivary $\mathrm{pH}<5.5$ when taking individual doses of 
Antoniya Pomakova, Nataliya Gateva, Nina Milcheva

the homeopathic drug may be a potential threat to the dentition (Table 3). Depending on their composition, frequency of application, and length of therapy, the oral health of children undergoing regular homeopathic treatment should be monitored (4). For comparison between our study and Subramaniam and Kumar's, we have used the common chamomilla medication. The mean values of $\mathrm{pH}$ drop after use in their study are higher than those observed in ours: 1.07 ( $15^{\text {th }}$ minute), 0.82 ( $30^{\text {th }}$ minute), 0.59 ( $60^{\text {th }}$ minute), while by Subramaniam and Kumar these are $1.72\left(15^{\text {th }}\right), 1.13\left(30^{\text {th }}\right), 0.88\left(60^{\text {th }}\right)$. Probably the reason is the different methodology used for collecting saliva samples and defining its $\mathrm{pH}$.

We found a drop in saliva $\mathrm{pH}$ in $100 \%$ of the cases, and lower values remained in over $80 \%$ at the end of the first hour. Thus, we have confirmed the studied scientific hypothesis that the intake of these homeopathic drugs results in a rapid drop in salivary $\mathrm{pH}$ values and this drop remains within one hour. This also provides grounds to doubt a possible negative effect following the intake of certain homeopathic medications on the conditions in the oral cavity. We also found cases where recovery of baseline $\mathrm{pH}$ is observed - in two cases at the $30^{\text {th }}$ minute and in three - at the $60^{\text {th }}$ minute (Table 6 and 7). This fact

Table 5. pH changes within one hour - control

\begin{tabular}{lccc|c|}
\hline Subject & $\begin{array}{c}\text { Initial } \\
\text { value }\end{array}$ & $\begin{array}{c}15^{\text {th }} \\
\text { minute }\end{array}$ & $\begin{array}{c}30^{\text {th }} \\
\text { minute }\end{array}$ & $\begin{array}{c}60^{\text {th }} \\
\text { minute }\end{array}$ \\
1 & 6.2 & 6.4 & 6.2 & 6.2 \\
2 & 6.8 & 6.8 & 6.8 & 6.8 \\
3 & 6.4 & 6.6 & 6.6 & 6.6 \\
4 & 6.4 & 6.4 & 6.6 & 6.6 \\
5 & 6.6 & 6.6 & 6.6 & 6.8 \\
6 & 6.4 & 6.4 & 6.4 & 6.4 \\
7 & 6.8 & 7.0 & 7.0 & 7.0 \\
8 & 6.6 & 6.6 & 6.6 & 6.6 \\
9 & 7.0 & 7.0 & 6.8 & 7.0 \\
10 & 6.2 & 6.2 & 6.4 & 6.2 \\
11 & 6.4 & 6.4 & 6.4 & 6.4 \\
12 & 6.4 & 6.4 & 6.6 & 6.6 \\
13 & 6.6 & 6.6 & 6.6 & 6.6 \\
14 & 6.6 & 6.4 & 6.6 & 6.6 \\
15 & 6.8 & 6.8 & 6.8 & 7.0 \\
16 & 6.6 & 6.8 & 6.6 & 6.6 \\
17 & 7.0 & 6.8 & 7.0 & 6.8 \\
18 & 6.8 & 6.8 & 6.8 & 6.8 \\
\hline
\end{tabular}

Table 6. pH changes within one hour - pellets

\begin{tabular}{lcccc} 
Subject & $\begin{array}{c}\text { Initial } \\
\text { value }\end{array}$ & $\begin{array}{c}15^{\text {th }} \\
\text { minute }\end{array}$ & $\begin{array}{c}30^{\text {th }} \\
\text { minute }\end{array}$ & $\begin{array}{c}60^{\text {th }} \\
\text { minute }\end{array}$ \\
1 & 6.2 & 5.5 & 5.8 & 5.8 \\
2 & 6.6 & 6.0 & 6.2 & 6.2 \\
3 & 6.4 & 5.4 & 5.8 & 5.8 \\
4 & 6.6 & 6.2 & 6.4 & 6.4 \\
5 & 6.8 & 6.2 & 6.4 & 6.4 \\
6 & 6.6 & 5.8 & 6.2 & 6.2 \\
7 & 7.2 & 6.0 & 6.2 & 6.2 \\
8 & 6.4 & 6.0 & 6.4 & 6.4 \\
9 & 7.0 & 6.8 & 7.0 & 7.0 \\
10 & 6.2 & 5.5 & 5.5 & 5.8 \\
11 & 6.6 & 6.0 & 6.0 & 6.2 \\
12 & 6.4 & 5.4 & 5.4 & 5.8 \\
13 & 6.6 & 6.0 & 6.2 & 6.4 \\
14 & 6.6 & 6.2 & 6.2 & 6.2 \\
15 & 6.8 & 6.2 & 6.2 & 6.4 \\
16 & 6.6 & 5.5 & 5.8 & 5.8 \\
17 & 7.0 & 6.0 & 6.2 & 6.4 \\
18 & 7.0 & 6.6 & 6.8 & 6.8 \\
\hline \hline
\end{tabular}

we attribute to differences in the saliva properties in different individuals - speed, quantity, composition, and buffer capacity.

Low saliva $\mathrm{pH}$ levels are detected after the intake of the homeopathic syrup. We suppose this is

Table 7. pH changes within one hour - syrup

\begin{tabular}{l|c|ccc} 
Subject & $\begin{array}{c}\text { Initial } \\
\text { value }\end{array}$ & $\begin{array}{c}15^{\text {th }} \\
\text { minute }\end{array}$ & $\begin{array}{c}30^{\text {th }} \\
\text { minute }\end{array}$ & $\begin{array}{c}60^{\text {th }} \\
\text { minute }\end{array}$ \\
1 & 6.8 & 5.4 & 5.6 & 6.2 \\
2 & 6.6 & 6.2 & 6.4 & 6.8 \\
3 & 6.2 & 5.2 & 5.4 & 5.8 \\
4 & 6.8 & 6.0 & 6.2 & 6.4 \\
5 & 6.8 & 5.4 & 5.6 & 5.8 \\
6 & 7.0 & 6.2 & 6.4 & 6.8 \\
7 & 6.4 & 6.2 & 6.2 & 6.4 \\
8 & 6.6 & 5.4 & 5.8 & 6.2 \\
9 & 7.4 & 6.0 & 6.2 & 6.4 \\
10 & 6.2 & 5.4 & 5.8 & 5.8 \\
11 & 6.4 & 5.8 & 6.0 & 6.4 \\
12 & 6.6 & 5.2 & 5.4 & 5.8 \\
13 & 6.4 & 6.0 & 6.0 & 6.2 \\
14 & 6.6 & 5.4 & 5.6 & 6.0 \\
15 & 6.6 & 5.8 & 5.8 & 6.0 \\
16 & 6.8 & 6.2 & 6.2 & 6.4 \\
17 & 6.8 & 5.2 & 5.6 & 5.8 \\
18 & 7.0 & 6.0 & 6.0 & 6.4 \\
\hline \hline
\end{tabular}


Table 8. pH changes within one hour - granules

\begin{tabular}{lcccc} 
Subject & $\begin{array}{c}\text { Initial } \\
\text { value }\end{array}$ & $\begin{array}{c}15^{\text {th }} \\
\text { minute }\end{array}$ & $\begin{array}{c}30^{\text {th }} \\
\text { minute }\end{array}$ & $\begin{array}{c}60^{\text {th }} \\
\text { minute }\end{array}$ \\
1 & 7.6 & 6.4 & 6.8 & 6.8 \\
2 & 6.4 & 5.4 & 5.8 & 5.8 \\
3 & 6.2 & 5.0 & 5.2 & 5.4 \\
4 & 6.0 & 5.2 & 5.4 & 5.8 \\
5 & 6.8 & 5.4 & 5.8 & 6.4 \\
6 & 6.6 & 5.4 & 5.6 & 6.0 \\
7 & 6.4 & 5.8 & 5.8 & 6.0 \\
8 & 6.4 & 6.0 & 6.0 & 6.2 \\
9 & 6.8 & 5.8 & 6.0 & 6.0 \\
10 & 7.0 & 6.0 & 6.4 & 6.4 \\
11 & 6.6 & 5.4 & 5.6 & 6.0 \\
12 & 6.6 & 5.0 & 5.4 & 5.8 \\
13 & 6.2 & 5.2 & 5.2 & 5.4 \\
14 & 6.8 & 5.4 & 5.8 & 6.0 \\
15 & 6.8 & 5.4 & 5.8 & 5.8 \\
16 & 6.2 & 5.6 & 5.6 & 6.0 \\
17 & 6.8 & 5.8 & 6.2 & 6.4 \\
18 & 6.8 & 5.6 & 5.8 & 6.2 \\
\hline
\end{tabular}

due to its high sucrose content, its low viscosity, and its acidic endogenous $\mathrm{pH}$. These factors have been proven to be crucial in a number of similar studies of conventional medications and especially pediatric liquid ones (19-25). The most significant drop in $\mathrm{pH}$ we determined was that following intake of homeopathic chamomile extract granules. Perhaps the reason for this is the longer retention in the oral cavity until full absorption. These facts provide an idea for a future study in this field and such on homeopathic medications - their composition, endogenous $\mathrm{pH}$, titratable acidity, effects of different viscosity and form of medications.

There is a high incidence of $\mathrm{pH}$ drops below the critical 5.5 with most cases after chamomile use - more than $50 \%$ at the $15^{\text {th }}$ minute, and in some volunteers this low value remains an hour later (Tab. 3). Therefore there is predominance of demineralisation processes in the oral cavity, which is a precondition for the initiation of a dental caries process. We believe that, combined with poor eating habits, poor oral hygiene and/or genetic predisposition, this could help increase the risk of dental caries.

\section{CONCLUSION}

The present study finds a significant drop in salivary $\mathrm{pH}$ following the intake of some homeopathic medications. An alarming fact is also the failure of $\mathrm{pH}$ to recover its baseline values even $60 \mathrm{~min}$ utes after taking the medication, and in a significant number of cases the $\mathrm{pH}$ remains in the range of 5.5 to 6 . This, along with the specific rules for the intake of homeopathic medications and their use at the patient's own discretion without prescription, makes them a factor in the risk assessment system for the development of a caries process. Healthcare professionals and patients should apply prophylactic measures to limit the potential side effects that sugar-containing medications, including homeopathic ones, may have on the oral health.

\section{ACKNOWLEDGMENT}

The authors thank for the support of volunteer patients and their participation in this study.

\section{REFERENCES}

1. Bhateja S, Arora G, Mahna R. Complementary \& alternative therapy in dentistry: homeopathy-a review. Annals and essences of dentistry 2013;3:36-40.

2. Mourão LC, Moutinho H, Canabarro A. Additional benefits of homeopathy in the treatment of chronic periodontitis: a randomized clinical trial. Complement Ther Clin Pract. 2013; 19(4):246-50. doi: 10.1016/j.ctcp.2013.05.002

3. Smith K. Against homeopathy - a utilitarian perspective. Bioethics. 2012;26(8):398-409. doi: 10.1111/j.1467-8519.2010.01876.X

4. Subramaniam $\mathrm{P}, \mathrm{Kumar} \mathrm{K}$. Change in salivary $\mathrm{pH}$ following use of homeopathic medicines: a preliminary study. Eur J Gen Dent. 2013;2(1):31-6. doi: $10.4103 / 2278-9626.106802$

5. Witt CM, Lüdtke R, Baur R, Willich SN. Homeopathic medical practice: longterm results of a cohort study with 3981 patients. BMC Public Health. 2005;5(3):115-23. doi: 10.1186/1471-2458-5-115

6. Bhat SS, Sargod SS, George D. Dentistry and homeopathy: an overview. Dent Update. 2005;32(8):486-8.

7. Upadhyay RP, Nayak C. Homeopathy emerging as nanomedicine. Ind J Res Homoeopathy 2012;6(3):31-8. 
Antoniya Pomakova, Nataliya Gateva, Nina Milcheva

8. Amoroso P, Ávila FA, Gagliardi CM. Prevalence of different Streptococci species in the oral cavity of children and adolescents. Braz J Oral Sci. 2003;2(4):164-8. doi: 10.20396/bjos.v2i4.8641674

9. Ayele FA, Taye BW, Ayele TA, Gelaye KA. Predictors of dental caries among children 7-14 years old in Northwest Ethiopia: a community based crosssectional study. BMC Oral Health. 2013;13-27. doi:10.1186/1472-6831-13-7.

10. Ferreira-Nóbilo Nde P, Tabchoury C, Sousa Mda L, Cury JA. Knowledge of dental caries and salivary factors related to the disease: influence of the teaching-learning process. Braz Oral Res. 2015;29(1):1-7. doi: 10.1590/1807-3107BOR-2015.vol29.0061

11. Guo L, Hu W, He X, Lux R, McLean J, Shi W. Investigating acid production by Streptococcus mutans with a surface-displayed $\mathrm{pH}$-sensitive green fluorescent protein. PLoSONE. 2013;8(2):e57182. doi:10.1371/journal.pone.0057182

12. Stephan RM. Changes in hydrogen-ion concentration on tooth surfaces and in carious lesions. JADA. 1940;27(5):718-23. doi: 10.14219/jada. archive.1940.0178

13. Xiao J, Klein MI, Falsetta ML, Lu B, Delahunty CM, Yates JR III, et al. The Exopolysaccharide Matrix Modulates the Interaction between 3D Architecture and Virulence of a Mixed-Species Oral Biofilm. PLoS Pathog 2012;8(4): e1002623. doi: 10.1371/ journal.ppat.1002623

14. Vroom JM, DeGrauw KJ, Gerritsen HC, Bradshaw DJ, Marsh PD, Watson GK et al. Depth penetration and detection of $\mathrm{pH}$ gradients in biofilms by twophoton excitation microscopy. Appl Environ Microbiol. 1999;65(8):3502-11.

15. The Free Library. Alternative medicine for the dental professional. 2009, American Dental Hygienists' Association 27 May. 2017. Available from: https:// www.thefreelibrary.com/Alternative+medicine+for +the+dental+professional.-a0193298316

16. Fry J, Brooks D, McColl I. NHS data Book. Lancaster: MTP Press;1984.

17. Feigal RJ, Gleeson MC, Beckman TM, Greenwood ME. Dental caries related to liquid medication intake in young patients. ASDC J Dent Child. 1984;51(5):360-2.

18. Paramesh H. Epidemiology of asthma in India. Indian J Pediatr. 2002;69(4):309-12. doi:10.1007/ BF02723216
19. Nankar M, Walimbe H, Bijle M, Kontham U, Kamath A, Muchandi S. Comparative evaluation of cariogenic and erosive potential of commonly prescribed pediatric liquid medicaments: An in vitro study. J Contemp Dent Pract. 2014;15(1):20-5. doi: 10.5005/jp-journals-10024-1481

20. Nirmala S.V.S.G., Popuri VD, Chilamakuri S, Nuvvula S, Veluru S, Babu MS. Oral health concerns with sweetened medicaments: Pediatricians' acuity. J Int Soc Prevent Community Dent. 2015; 5(1):35-9. doi: 10.4103/2231-0762.151973

21. Pierro VS, Abdelnur JP, Maia LC, Trugo LC. Free sugar concentration and $\mathrm{pH}$ of paediatric medicines in Brazil. Community Dent Health. 2005;22(3):180-3.

22. Saeed S, Bshara N, Trak J, Mahmoud G. An in vitro analysis of the cariogenic and erosive potential of pediatric liquid analgesics. J Indian Soc Pedod Prev Dent. 2015; 33(2):143-6. doi: 10.4103/0970-4388.155129

23. Valinoti AC, da Silva Pierro VS, da Silva EM, Maia LC. In vitro alterations in dental enamel exposed to acids medicines. Int J Paed Dent. 2011; 21(2):141150. doi: 10.1111/j.1365-263X.2010.01104.x

24. Sahgal J, Sood PB, Raju OS. A comparison of oral hygiene status and dental caries in children on long term liquid oral medications to those not administered with such medications. J Indian Soc Pedod Prev Dent. 2002;20(4):144-151.

25. Rekola M. In vivo acid production from medicines in syrup form. Caries Res. 1989;23(6):412-6. doi: $10.1159 / 000261219$

26. Eames S, Darby P. Homeopathy and its ethical use in dentistry. Br Dent J. 2011;210(7):299-301. doi: 10.1038/sj.bdj.2011.237

27. Barry C. The Body, Health and Healing in Alternative and Integrated Medicine: An Ethnography of Homeopathy in South London. Brunel University; 2003.

28. Hahnemann S, O'Reily WB, editor. Organon of the Medical Art. Palo Alto, California (USA): Birdcage Books; 1996. 